\title{
Statement on the Publication of Alice Dreger's Investigation, Darkness's Descent on the American Anthropological Association: A Cautionary Tale
}

\author{
Jane B. Lancaster • Raymond Hames
}

Published online: 19 February 2011

(C) Springer Science+Business Media, LLC 2011

Keywords American Anthropological Association - Anthropology · Darkness in El Dorado $\cdot$ Science

We feel it is important to explain to the readership of Human Nature why we decided to break with our tradition of publishing only those papers based on evolutionary approaches to human behavior that are highly empirical in terms of substantive testing of theoretical predictions with data. Our decision to publish an investigation of the conduct of a professional society needs to be explained to those who are not aware of the history that lies behind it. Although the readers of Human Nature come from a wide variety of disciplines, a solid core of both readers and Consulting Editors identify themselves as Evolutionary Anthropologists or Human Evolutionary Ecologists, do research in nonindustrialized societies, and practice scientific methodology. This is the group that was most damaged in reputation and status by the original publication in 2001 of Darkness in El Dorado by Patrick Tierney (New York: W. W. Norton) and, that same year, by the President and Executive Board of the American Anthropological Association, who launched an unstructured investigation into accusations of scientifically motivated genocide against James Neel, a geneticist, and Napoleon Chagnon, an anthropologist.

Evolutionary anthropologists were very disturbed by what seemed to be a witchhunting psychology that rippled through the AAA meetings, the AAA-sponsored investigation, and subsequent web postings. A number of us decided that we needed

\footnotetext{
J. B. Lancaster $(\bowtie)$

Department of Anthropology, University of New Mexico, MSC 01-1040, Albuquerque, NM 87131-0001, USA

e-mail: jlancas@unm.edu

R. Hames

Department of Anthropology, University of Nebraska, Lincoln, NE 68583-0218, USA

e-mail: rhames@unl.edu
} 
to legitimize ourselves and our students' presence in the AAA by forming a new section, the Evolutionary Anthropology Society (EAS), rather than forming a separate society as had the membership of the American Association of Physical Anthropology and the Human Biology Association. As part of this formation of a new AAA section, Human Nature came to an agreement with EAS that it would be the section's associated journal, offer a reduced subscription price, and dedicate a special issue each year to one of the section's organized sessions. That we have done since EAS's inception in 2005. This arrangement has been very successful, and, until this past year, EAS members were satisfied that their goal was accomplished.

Unfortunately, we now know that this is not at all past history. In November 2010 the President and Executive Board of the AAA released a new version of the AAA Long Range Plan. The Long Range Plan is a short but potent document composed of 178 words presented in three brief sections. From the existing statement, the word science was struck four times - that is, each and every time it occurred - in favor of such wording as public understanding. Almost immediately, a series of editorials and commentaries were published in The New York Times, The Chronicle of Higher Education, Inside Higher Ed, and Psychology Today. The AAA President and Executive Board began backtracking with claims that these articles were the work of complainers, pundits, and extremists and not the supposedly contented membership of the AAA. However, within a few weeks the Council Assembly of the 34 official AAA Sections clearly expressed a very different position and unanimously passed a resolution requesting that science be reinstated to a position on par with humanistic approaches. To fully appreciate the significance of this resolution, one must understand that when one joins the AAA, one must declare membership in at least one of the 34 sections that represent the member's interests, such as the Society for Humanistic Anthropology, the Association for Africanist Anthropology, etc. Getting 34 primarily academic professionals to agree on anything is remarkable and sends a powerful message. In the original Darkness in El Dorado controversy, the AAA President and Executive Board showed themselves to be similarly disassociated from the membership, which had in two official ballot referenda first repudiated the Task Force's final report and then called for its complete rescission. Apparently no lessons were learned from that experience. This is why Alice Dreger's history is so important. She documents the extent to which the leadership of the AAA broke their own bylaws, relied on a sensationalistic work judged by most experts to be without empirical foundation in its major claims, and ignored rules of fair play in their persecution of two scientists.

Science has a special place and currency in American society. Purging science from the AAA's Long Range Plan will lose us our credibility, the ability to testify and advocate for effective change, and hence our power to do good. We become just another special interest group by abandoning evidence-based testimony which trumps special interest group advocacy in the courts, public opinion, and the legislative process. So once again the status of science in anthropology has been challenged. Scientific anthropologists merit full respect and backing and should not be pushed into corners or swept under a rug or even worse, as Alice Dreger documents (DOI 10.1007/s12110-011-9103-y, Human Nature 2011), come under attack by our own major professional organization to pacify those who initiated a witch hunt. 